\title{
TEKNOLOGI REDUKSI SAMPAH ORGANIK BERBASIS LARVA BLACK SOLDIER FLY (HERMETIA ILLUCENS) DENGAN VARIASI FREKUENSI FEEDING
}

\author{
ORGANIC WASTE REDUCTION TECHNOLOGY BASED ON BLACK SOLDIER FLY
}

(HERMETIA ILLUCENS) LARVA WITH VARIATION OF FEEDING FREQUENCY

\section{Novi Rahmadayanti ${ }^{1}$ dan Muhammad Firmansyah ${ }^{2}$}

${ }^{1}$ Mahasiswa Program Studi Teknik Lingkungan, Fakultas Teknik, Universitas Lambung Mangkurat, ${ }^{2}$ Dosen Program Studi Teknik Lingkungan, Fakultas Teknik, Universitas Lambung Mangkurat, Jl. Jend. A. Yani Km 36, Banjarbaru, Kalimantan Selatan, 70714, Indonesia

Email:1710815120018@mhs.ulm.ac.id

\begin{abstract}
Abstrak
Melihat banyaknya timbulan sampah berupa sampah organik yang dihasilkan masyarakat, terlihat potensi untuk mereduksi sampah organik dengan berbagai metode yang banyak dikembangkan dan diaplikasikan di Indonesia, dari sekian banyak alternative cara pereduksi salah satunya adalah dengan menggunakan larva dari lalat jenis Black Soldier Fly (Hermetia illucens). Penelitian ini dilakukan dengan metode percobaan skala laboratorium. Sampah organic yang digunakan sebagai sampel adalah sampah sayur dan buah. Tujuan dari penelitian ini untuk menganalisis persentase kemampuan larva BSF dalam mereduksi sampah organic buah dan sayur. Metode yang digunakan pada penelitian adalah Rancangan Acak Lengkap (RAL) dengan 2 kali pengulangan. Analisis data yang digunakan adalah Analysis of Variance (ANNOVA). Larva yang digunakan pada penelitian ini adalah 350 ekor dengan frekuensi feeding 1 hari, 3 hari dan 5 hari dengan massa feeding 1,5 kg dan $18 \mathrm{ml}$ EM4. Hasil kajian menunjukkan bahwa, persentase terbesar reduksi sampah oleh larva BSF untuk reduksi sampah buah dan sayur dengan frekuensi feeding 1, 3 dan 5 hari sebesar 71\%, 70\% dan $60 \%$. Berdasarkan persentase tersebut dapat ditentukan bahwa frekuensi feeding sekali dalam sehari lebih efektif untuk menghasilkan reduksi sampah yang lebih optimal.
\end{abstract}

Kata kunci: EM4, Frekuensi Feeding, Larva BSF, Reduksi Sampah Organik

\section{ABSTRACT}

Seeing the amount of waste in the form of organic waste produced by the community, there is the potential to reduce organic waste with various methods that are widely developed and applied in Indonesia, from many alternative ways of reducing one of them is by using larvae from flies type Black Soldier Fly (Hermetia illucens). This research was conducted by laboratory scale experiment method. Organic waste used as samples is vegetable and fruit waste. The purpose of this study is to analyze the percentage of BSF larvae' ability to reduce organic waste of fruits and vegetables. The method used in the study was Complete RandomIzed Design (RAL) with 2 repetitions. The data analysis used is Analysis of Variance (ANNOVA). The larvae used in this study were 350 heads with feeding frequency of 1 day, 3 days and 5 days with feeding mass of $1.5 \mathrm{~kg}$ and $18 \mathrm{ml}$ of EM4. The results showed that, the largest percentage of waste reduction by BSF larvae for the reduction of fruit and vegetable waste with feeding frequency of 1, 3 and 5 days by $71 \%, 70 \%$ and $60 \%$. Based on these percentages can be determined that the frequency of feeding once a day is more effective to produce more optimal waste reduction.

Keywords: EM4, Feeding Frequency, BSF larvae, Organic Waste Reduction 


\section{PENDAHULUAN}

Kementerian Lingkungan Hidup dan Kehutanan (KLHK) menyampaikan jumlah sampah di Indonesia telah mencapai 175.000 ton/hari atau setara 64 juta ton/tahun yang dihasilkan setiap orang/hai sebesar $0.7 \mathrm{~kg}$ jenis sampah yang mendominasi adalah sampah organik $50 \%$ seperti sisa makanan, sayuran maupun buah-buahan, plastik sebesar 15\%, dan kertas sebesar 10\% kemudian sisa lainnya berupa logam, karet, kain dan kaca (Cintaningtyas, dkk. 2020). Melihat banyaknya timbulan sampah berupa sampah organik yang dihasilkan masyarakat, terlihat potensi untuk mereduksi sampah organik dengan berbagai metode yang banyak dikembangkan dan diaplikasikan di Indonesia mulai dari metode sederhana sampai yang menggunakan peralatan canggih, dari sekian banyak alternative cara pereduksi salah satunya adalah dengan menggunakan larva dari lalat jenis Black Soldier Fly (Hermetia illucens) (Nursaid, dll. 2019).

Penelitian ini dilakukan dengan metode pemanfaatan larva BSF untuk mendekomposisi sampah organik. Sampah organik yang dijadikan sampel penelitian adalah sampah sayuran dan sampah buahbuahan yang nantinya ditambahkan dengan perlakuan pemberian cairan EM4. EM4 sendiri mengandung $90 \%$ bakteri Lactobacillus sp. (bakteri penghasil asam laktat) pelarut fosfat, bakteri fotosintetik, Streptomyces sp, jamur pengurai selulosa dan ragi. EM4 merupakan suatu tambahan untuk mengoptimalkan pemanfaatan zat-zat makanan karena bakteri yang terdapat dalam EM4 dapat mencerna selulosa, pati, gula, protein, lemak (Surung, 2008). Hasil penelitian yang ingin dicapai adalah persentase kemampuan larva BSF sebagai pereduksi sampah organik dan biomassa larva BSF.

\section{METODE PENELITIAN}

Penelitian ini dilakukan di Penangkaran BSF Hivea Barabai, Hulu Sungai Tengah, Kalimantan Selatan. Penelitian ini dilakukan dengan metode percobaan skala laboratorium. Penelitian ini dilaksanakan selama 3 bulan (90 hari) dengan waktu running penelitian 14 hari. Analisis data yang digunakan pada penelitian ini adalah Rancangan Acak Lengkap (RAL) dengan 2 kali pengulangan. Metode uji statistik yang digunakan adalah uji Annova One Way. Penelitian ini bertujuan untuk menganalisis persentase kemampuan reduksi larva BSF dan pengaruh variasi frekuensi feeding. Sampah organik yang digunakan adalah sampah sayuran dan buah-buahan. Hasil akhir penelitian yang ingin dicapai adalah mendapatkan persentase kemampuan BSF dalam mereduksi sampah organik dengan pengaruh variasi frekuensi feeding dan pemberian perlakuan yang dilakukan.

\section{HASIL DAN PEMBAHASAN}

\subsection{Penelitian Pendahuluan}

\subsubsection{Pengukuran pH Awal Sampel Sampah}

Pengukuran $\mathrm{pH}$ awal sampel diperlukan untuk mengetahui $\mathrm{pH}$ awal dari sampel sampah yang akan direduksi oleh larva BSF. Tinggi atau rendahnya $\mathrm{pH}$ dapat berpengaruh pada tingkat pertumbuhan larva dan proses reduksinya. 
Tabel 3. 1 Data Pengukuran pH Awal Sampel

\begin{tabular}{ccc}
\hline No. & Jenis Variasi Sampel & PH \\
\hline 1 & $\begin{array}{c}\text { Sampah buah } 80 \% \text { : sayur 20\% + EM4 18+350 } \\
\text { Larva + feeding 1 hari (AX) }\end{array}$ & 5,7 \\
2 & Sampah buah 80\% : sayur 20\% + EM4 18+350 & 5,5 \\
Larva + feeding 5 hari (AY) & \\
3 & Sampah buah 80\% : sayur 20\% + EM4 18 + 350 \\
Larva + feeding 3 hari (K) & 5,7 \\
\hline
\end{tabular}

Berdasarkan data yang diperoleh, pengukuran $\mathrm{pH}$ tertinggi diperoleh dari sampel sampah sayur $20 \%$ : buah $80 \%$ dengan EM4 dan frekuensi feeding satu hari dengan nilai pH 5,7 sama seperti perlakuan kontrol sampel sampah sayur 20\% : buah $80 \%$ dengan EM4 dan frekuensi feeding tiga hari juga memiliki nilai $\mathrm{pH}$ 5,7 sedangkan untuk $\mathrm{pH}$ rendah diperoleh dari sampel sampah sayur 20\% : buah 80\% dengan EM4 dan frekuensi feeding lima hari dengan nilai $\mathrm{pH}$ 5,5.

\subsubsection{Pengukuran Suhu Awal Sampel Sampah}

Pengukuran suhu dilakukan untuk mengetahui keadaan suhu pada sampel sampah yang akan diberikan kepada larva BSF. Kadar suhu pada sampel sampah akan mempengaruhi kehidupan larva BSF

Tabel 3. 2 Data Pengukuran Suhu Awal Sampel

\begin{tabular}{ccc}
\hline No. & Jenis Variasi Sampel & Suhu $\left({ }^{\circ} \mathrm{C}\right)$ \\
\hline 1 & Sampah buah $80 \%$ : sayur 20\% + EM4 18+350 & 27,5 \\
Larva + feeding 1 hari (AX) & \\
2 & Sampah buah 80\% : sayur 20\% + EM4 $18+350$ & 26,5 \\
Larva + feeding 5 hari (AY) & 28 \\
3 & Sampah buah 80\% : sayur 20\% + EM4 18 + 350 \\
& Larva + feeding 3 hari (K) & \\
\hline
\end{tabular}

Suhu optimal untuk pertumbuhan larva BSF adalah 25-36 ${ }^{\circ} \mathrm{C}$ (Jatmiko, 2021). Sampel sampah perlakuan kontrol buah 80\% : sayur 20\% (EM4 $18 \mathrm{ml}, 350$ larva dan frekuensi feeding 3 hari) memiliki suhu yang lebih tinggi dengan nilai $28^{\circ} \mathrm{C}$ dibandingkan dengan variasi lainnya, dan sampah buah $80 \%$ : sayur 20\% (EM4 $18 \mathrm{ml}, 350$ larva dan frekuensi feeding 5 hari) memiliki suhu lebih rendah dengan nilai $26^{\circ} \mathrm{C}$ dibandingkan dengan variasi lainnya.

\subsubsection{Pengukuran Kadar Air Awal Sampel Sampah}

Pengukuran kadar air sampah diperlukan untuk mengetahui kadar air yang diberikan kepada larva, karena kadar air dari subtrat dapat berdampak terhadap pertumbuhan larva BSF (Jatmiko, 2021). 
Tabel 3. 3 Data Pengukuran Kadar Air Awal Sampel

\begin{tabular}{ccc}
\hline No. & Jenis Variasi Sampel & Kadar Air (\%) \\
\hline 1 & Sampah buah 80\% : sayur 20\% + EM4 18 +350 & 50 \\
Larva + feeding 1 hari (AX) & 53 \\
3 & Sampah buah 80\% : sayur 20\% + EM4 18 + 350 \\
Larva + feeding 5 hari (AY) & 53 \\
2 & Sampah buah 80\% : sayur 20\% + EM4 18 + 350 \\
Larva + feeding 3 hari (K) & \\
\hline
\end{tabular}

Data pengukuran kadar air awal sampel sampah menunjukkan bahwa sampel sampah perlakuan kontrol, buah $80 \%$ : sayur 20\% dengan EM4 dan larva dengan frekuensi feeding tiga hari memiliki kadar air sebanyak 53\% sama dengan sampah variabel bebas, buah $80 \%$ : sayur 20\% dengan EM4 dan Larva dengan feeding 5 hari. Sedangkan, sampel sampah buah 80\% : sayur 20\% dengan EM4 dan larva dengan frekuensi feeding satu hari memiliiki kadar air sebanyak $50 \%$.

\subsection{Pengukuran Harian pH Sampel Sampah}

Pengukuran $\mathrm{pH}$ sampel sampah dilakukan setiap hari. Pengukuran harian $\mathrm{pH}$ dilakukan untuk melihat pengaruh proses reduksi larva BSF terhadap perubahan $\mathrm{pH}$ yang terjadi pada sampel sampah.

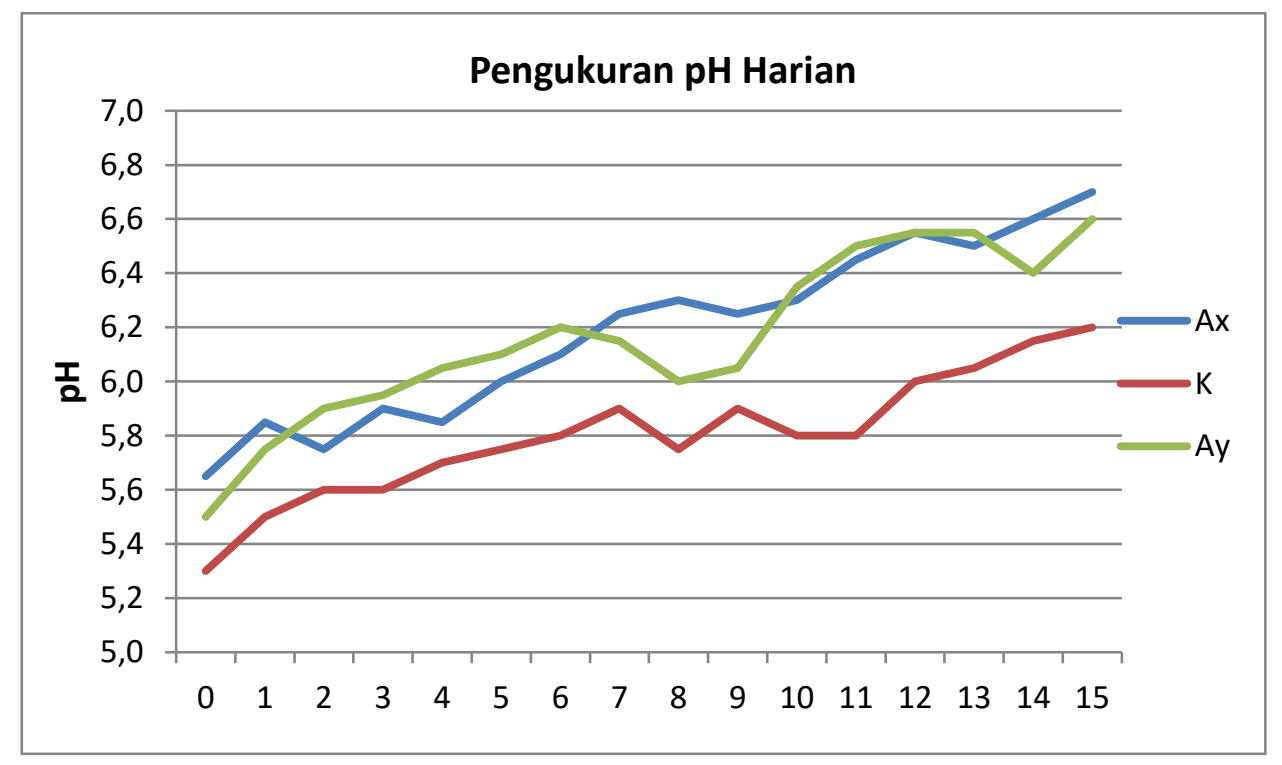

Gambar 3. 1 Grafik Pengukuran pH Harian Sampel Sampah

Berdasarkan Gambar 4.1 dapat diketahui bahwa $\mathrm{pH}$ pada semua reaktor yang berisi sampah buah $80 \%$ dan sayur 20\% degan frekuensi feeding 1, 3 dan 5 hari cenderung mengalami peningkatan selama penelitian dengan nilai $\mathrm{pH}$ awal 5,3 dan nilai $\mathrm{pH}$ akhir 6,7. Berdasarkan pengukuran $\mathrm{pH}$ pada reaktor yang berisi sampah buah $80 \%$ dan sayur $20 \%$ dengan frekuensi feeding 1 yang dilakukan dari hari pertama hingga hari ke-10 kondisi masing-masing sampel berada pada kondisi asam $(<7)$, 
dikarenakan sampah buah yang mendominasi pada reaktor tersebut adalah buah mangga (nilai $\mathrm{pH}$ 5.8-6.0), hari selanjutnya hingga hari ke-15 kondisi masing-masing sampel perlahan mendekati netral dengan nilai $\mathrm{pH}$ 6.5-6.7. Begitupun dengan reaktor control Kontrol (frek. 3 hari) dan reaktor AY (frek. 5 hari) pada hari selanjutnya hingga hari ke-15 perlahan-lahan mendekati netral.

\subsection{Pengukuran Harian Suhu Sampel Sampah}

Pengukuran suhu dilakukan setiap hari. Pengukuran dilakukan pada masing-masing reaktor. Pengukuran suhu harian pada sampel sampah dilakukan untuk mengetahui pengaruh suhu terhadap kehidupan larva BSF.

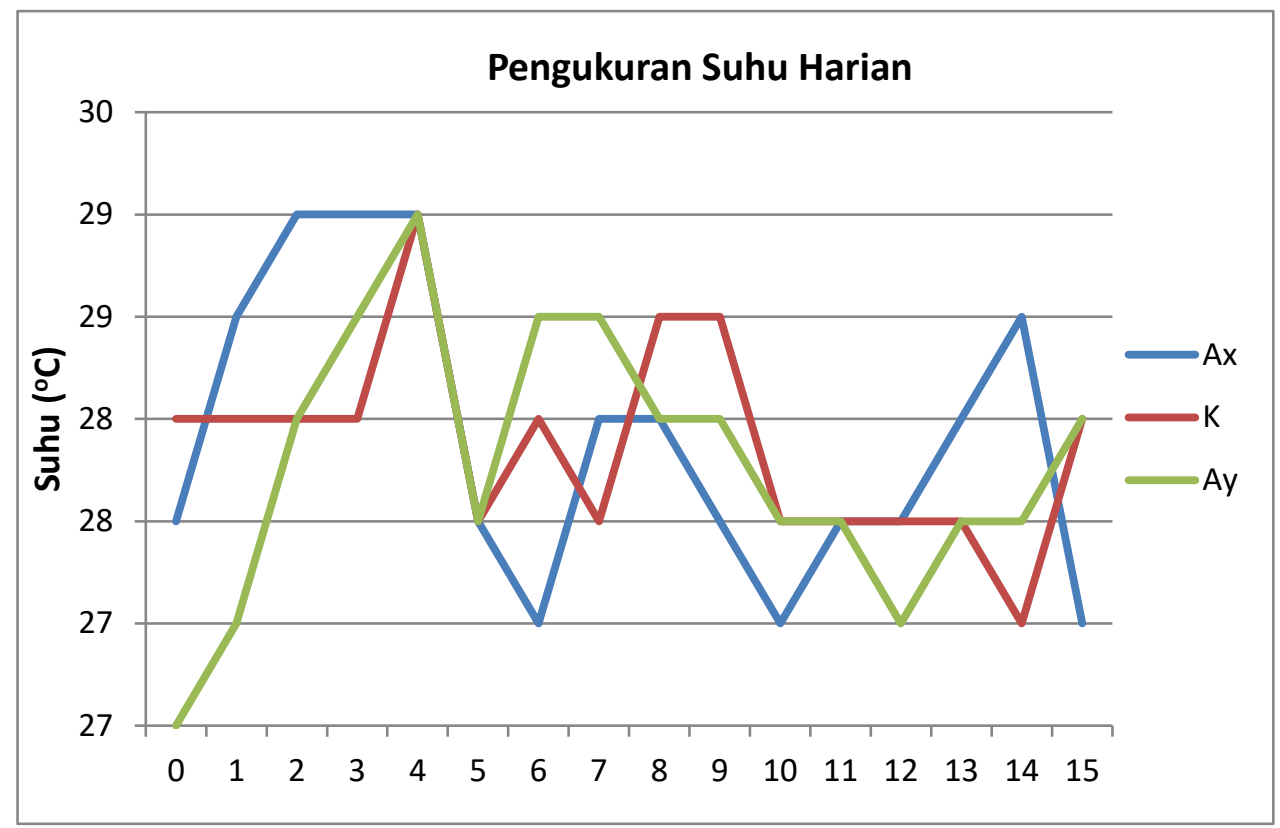

Gambar 3. 2 Grafik Pengukuran Suhu Harian Sampel Sampah

Berdasarkan Gambar 4.3 pengukuran suhu dari hari pertama hingga hari ke-15 pada reaktor variabel bebas cenderung memiliki pola yang fluktuatif. Pengukuran suhu pada reaktor yang berisi sampah buah $80 \%$ dan sayur $20 \%$ dengan frekuensi feeding 1, dari hari pertama hingga hari ke-15 running masing-masing sampel berada pada suhu normal yaitu berkisah antara $28-29^{\circ} \mathrm{C}$, diikuti dengan reaktor control (frek.3 hari) dan reaktor AY (frek. 5 hari).

\subsection{Pengukuran Harian Kadar Air Sampel Sampah}

Pengukuran kadar air dilakukan setiap hari. Pengukuran dilakukan pada masing-masing reaktor. Pengukuran kadar air dilakukan untuk mengetahui kandungan kadar air sampel sampah selama running penelitian. 


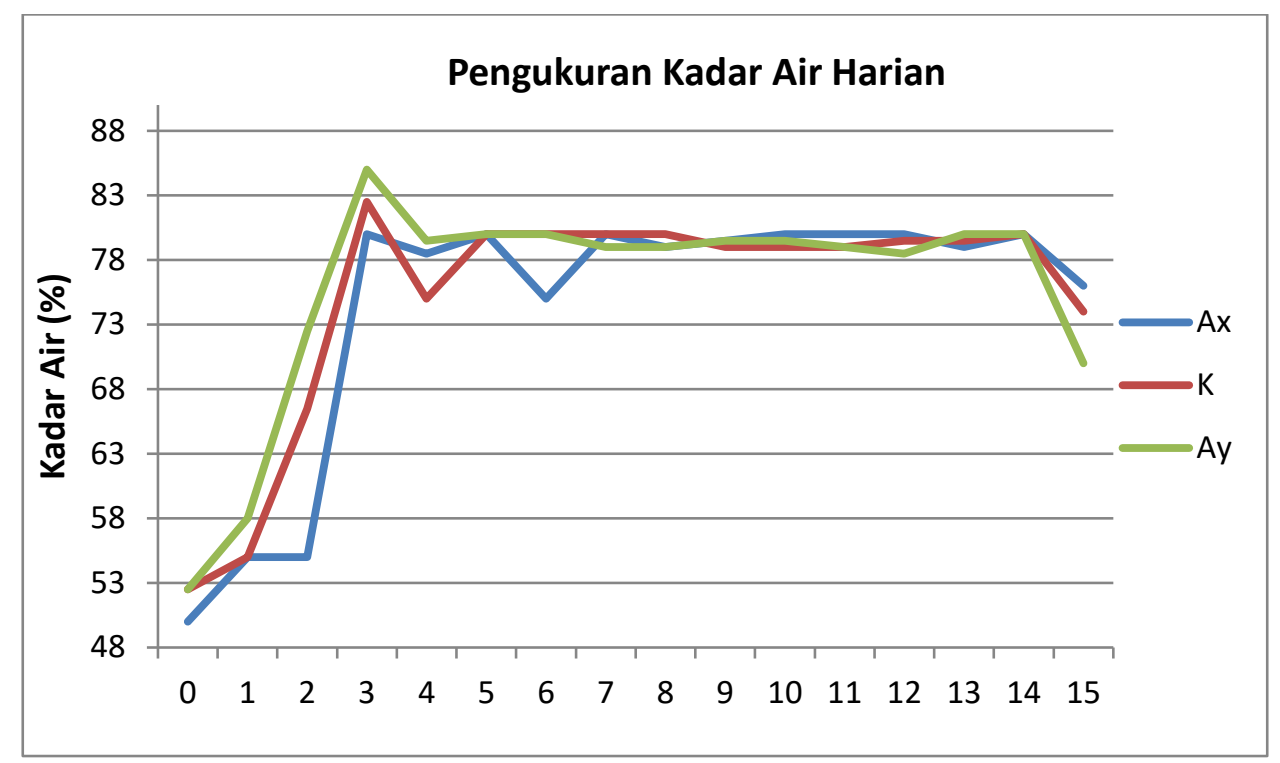

Gambar 3. 3 Grafik Pengukuran Kadar Air Harian Sampel Sampah

Berdasarkan Gambar 4.3 dapat diketahui bahwa sampel sampah pada semua reaktor mengalami peningkatan dari hari pertama sampai hari ke-15 penelitian. Pada reaktor AX (frek. 1 hari) kadar air mengalami peningkatan dan mengalami penurunan pada hari ke-15 dengan nilai $76 \%$. Reaktor AY (frek. 5 hari) juga mengalami penurunan kadar air pada hari ke-15 dengan nilai 70\%, reaktor Kontrol (frek. 3 hari) mengalami hal serupa pula dengan nilai akhir kadar air 75\%. Waktu konsumsi larva terhadap sampah yang diberikan dipengaruhi kadar air dimana kondisi optimum untuk kehidupan larva BSF adalah berkisar antara 60\%- 90\%.

\subsection{Pertambahan Biomassa Larva}

Pengukuran berat larva dilakukan dengan penimbangan $10 \%$ jumlah larva total, sebagai representatif berat total larva pada tiap reaktor (Diener et al., 2011). Penimbangan dilakukan terhadap 35 ekor larva (10\% dari total larva pada masing-masing reaktor).

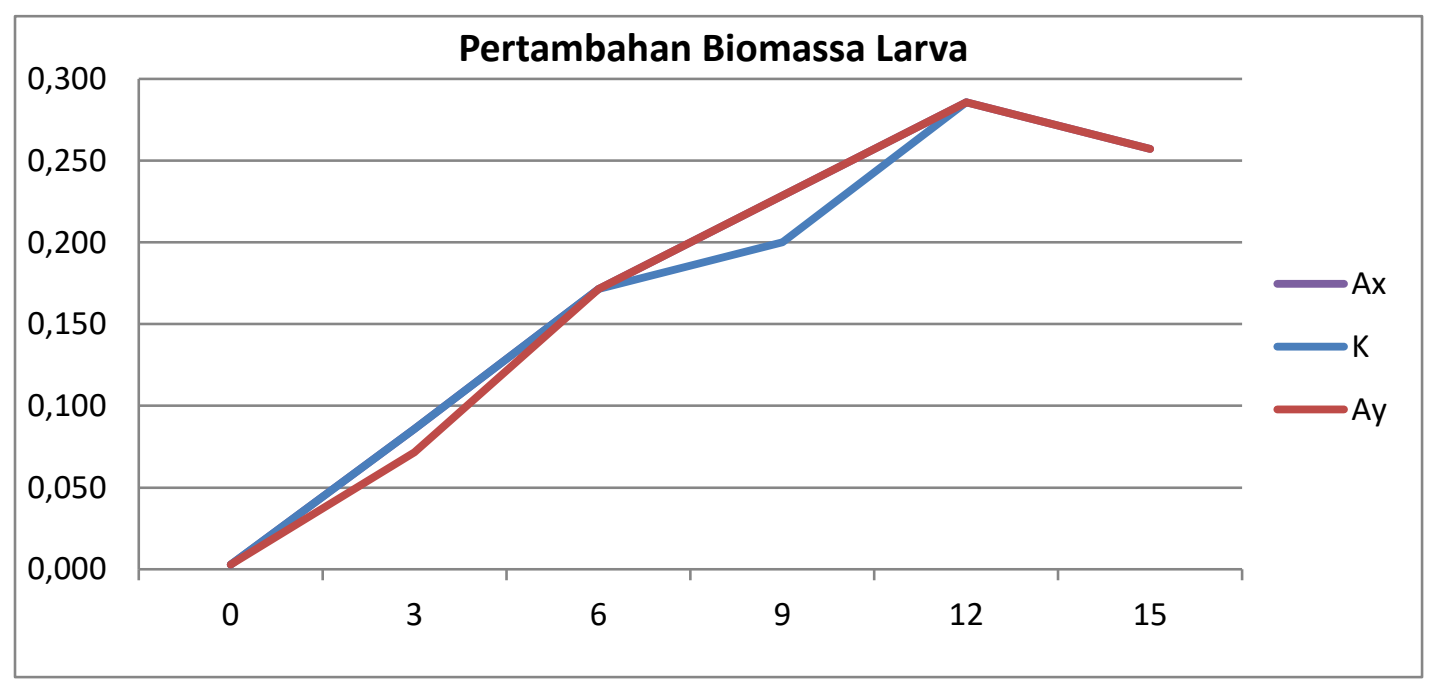

Gambar 3. 4 Grafik Pertambahan Biomassa Larva 
Berdasarkan Gambar 4.4, larva BSF yang ditemukan disetiap reaktor memiliki nilai biomassa yang hampir sama di setiap reaktor selama penelitian. Biomassa larva tertinggi dengan berat rata-rata 0,286 gram berada pada semua reaktor pada pengukuran hari ke-12, sedangkan untuk biomassa terendah pada reaktor sampah buah $80 \%$ : sayur 20\% dengan EM4 dan larva dengan frekuensi feeding 5 hari memiliki berat rata-rata 0,071 gram pada pengukuran hari ke-3. Peningkatan biomassa larva yang signifikan terjadi pada hari ke-0 hingga hari ke-12 dengan rata-rata penambahan berat 0,057 gram/ekor sampai 0,085 gram/ekor. Memasuki hari ke-15 terjadi penurunan berat karena larva BSF mulai memasuki fase prepupa, yang mana pada fase prepupa ini larva BSF tidak lagi memakan sampah yang berada dalam reaktor dikarenakan nutrisi dalam tubuhnya telah tercukupi (Rofi, 2020).

\subsection{Analisis Reduksi Sampel Sampah}

Efektivitas penentuan larva BSF dalam mereduksi sampah makanan dapat dilihat dari besarnya persentase reduksi sampah yang telah dilakukan. Persentase reduksi sampah yang telah dilakukan oleh larva BSF dihitung berdasarkan perbandingan berat total sampel sampah yang telah ditambahkan (Diener et al., 2011). Data hasil penelitian penambahan sampah dan residu hasil reduksi sampah dari hari ke-1 hingga hari ke-15 dapat dilihat pada Gambar 4.5, Gambar 4.6 dan Gambar 4.7. dan data dari indeks reduksi sampah dapat dilihat pada Tabel 4.4, Tabel 4.5 dan Tabel 4.6

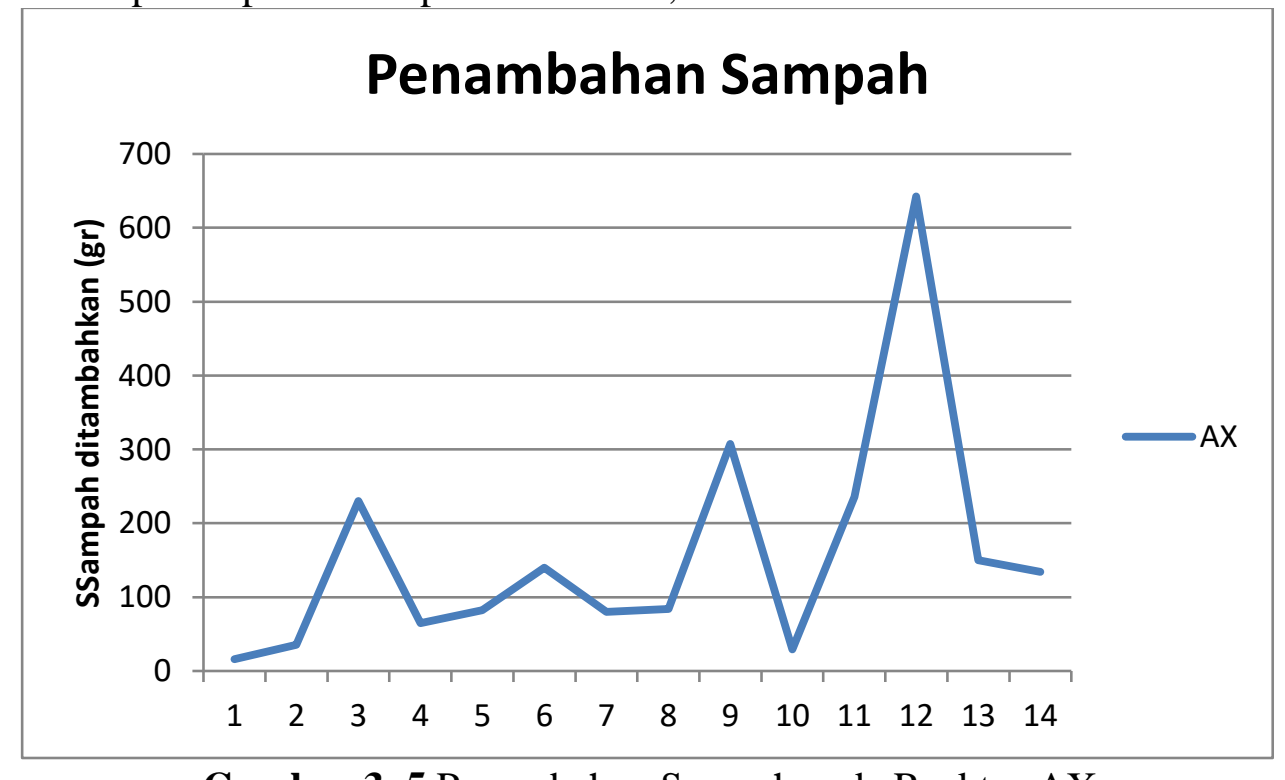

Gambar 3. 5 Penambahan Sampah pada Reaktor AX

Berdasarkan 4.5 penambahan sampel sampah dilakukan setiap hari dengan total penambahan sampah sebanyak 14 kali. Hasil akhir residu sampah yaitu dengan rata-rata residu padat sebesar 1065 gram dan residu cair $665 \mathrm{ml}$. Nilai tertinggi reduksi pada hari ke-12 dengan rata-rata sebesar 643 gram. Reduksi kembali mengalami penurunan dikarenakan larva telah memasuki fase prepupa. 


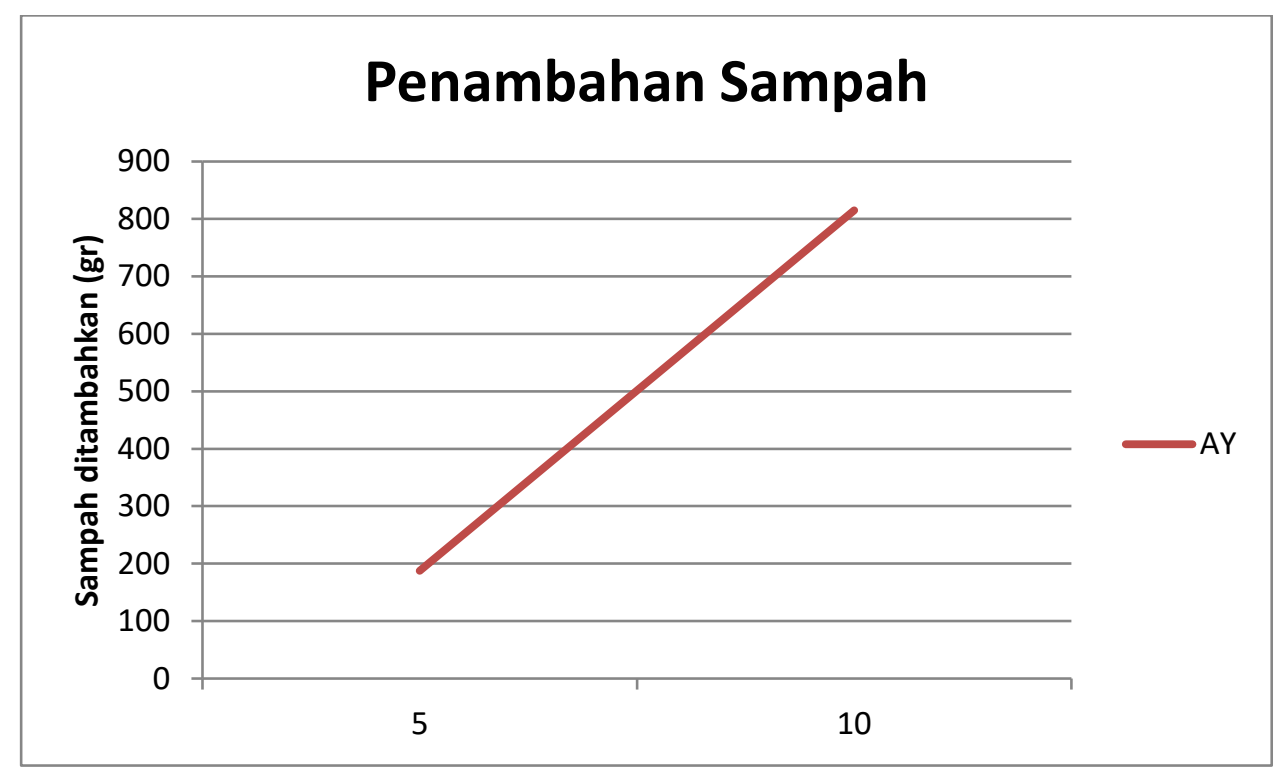

Gambar 3. 6 Penambahan Sampah pada Reaktor AY

Berdasarkan Gambar 4.6 penambahan sampel sampah dilakukan sekali dalam 5 hari dengan total penambahan sampah sebanyak 3 kali. Hasil akhir residu sampah dengan rata-rata residu padat sebesar 995 gram dan residu cair $930 \mathrm{ml}$. Nilai tertinggi reduksi pada hari ke-10 dengan rata-rata sebesar 815 gram. Reduksi kembali mengalami penurunan dikarenakan larva telah memasuki fase prepupa.

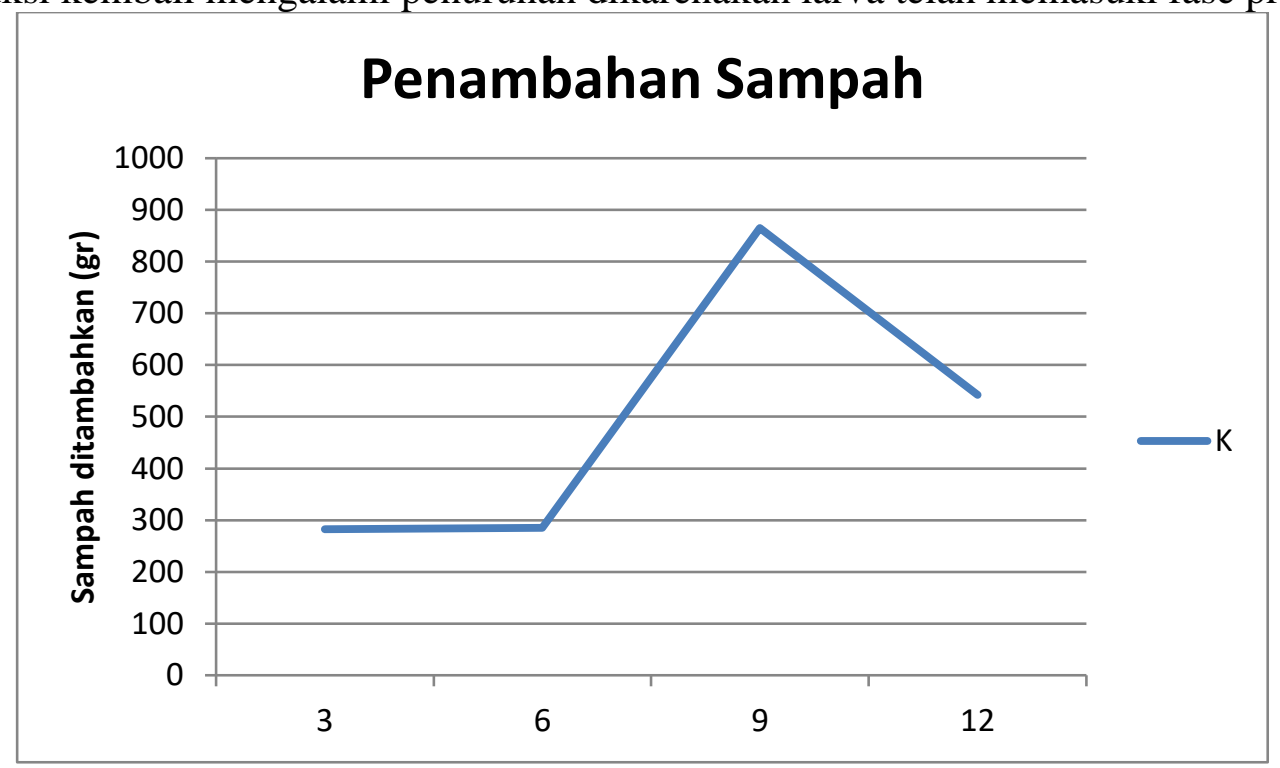

Gambar 3. 7 Penambahan Sampah pada Reaktor K

Berdasarkan Gambar 4.7 penambahan sampel sampah dilakukan sekali dalam 3 hari dengan total penambahan sampah sebanyak 5 kali. Hasil akhir residu padat sampah perlakuan kontrol dengan ratarata sebesar 1043 gram dan residu cair dengan rata-rata sebesar $792 \mathrm{ml}$. Nilai tertinggi reduksi pada hari ke-9 dengan rata-rata sebesar 865 gram. Reduksi kembali mengalami penurunan dikarenakan larva telah memasuki fase prepupa. 


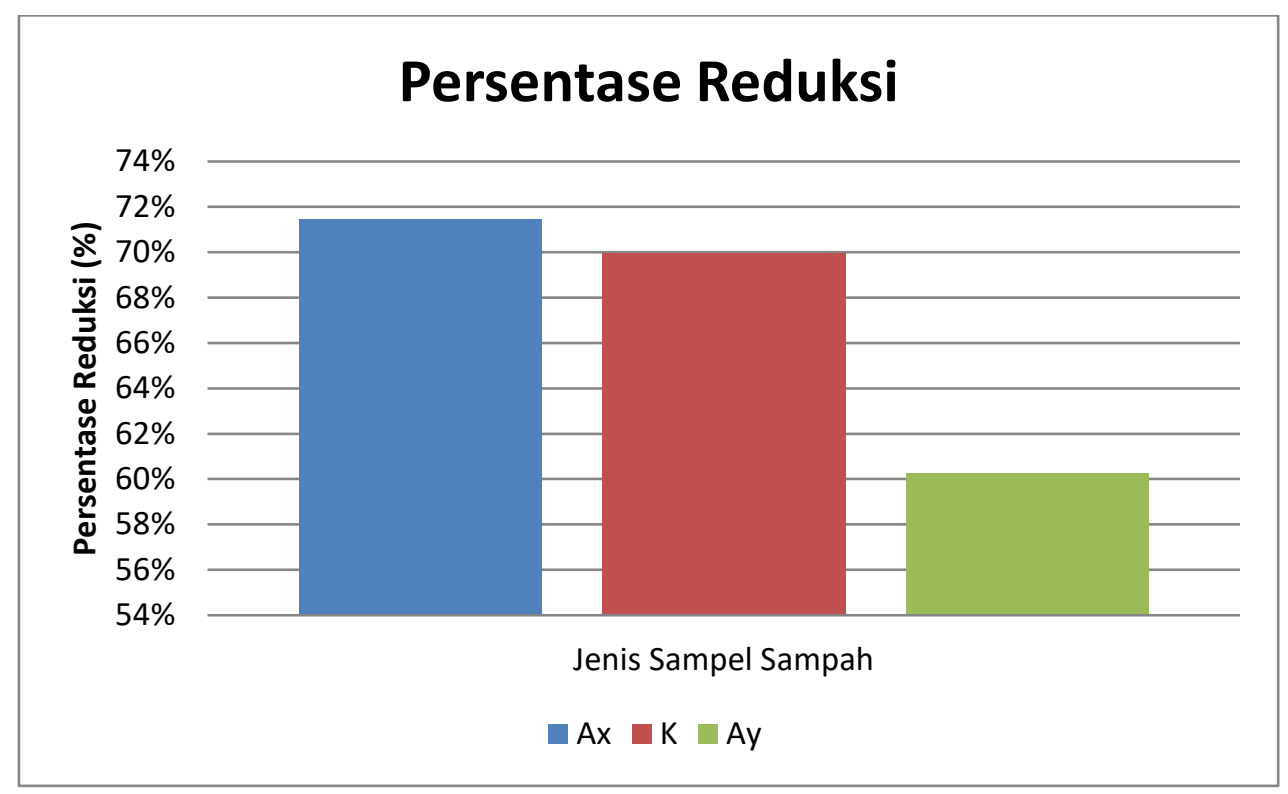

Gambar 3. 8 Grafik Persentase Reduksi Sampah

Berdasarkan Gambar 4.5 grafik persentase reduksi tertinggi ada pada reaktor AX (Feeding 1 hari + 350 larva + $18 \mathrm{ml} \mathrm{EM} 4+1.5 \mathrm{~kg}$ sampah) dengan persentase sebesar $71 \%$. Persentase reduksi terendah ada pada reaktor AY (Feeding 5 hari +350 larva $+18 \mathrm{ml} \mathrm{EM4} \mathrm{+} \mathrm{1.5kg} \mathrm{sampah)} \mathrm{dengan} \mathrm{persentase}$ sebesar 60\%. Dapat disimpulkan bahwa semakin besar frekuensi feeding maka semakin kecil pula persentase reduksi dan frekuensi feeding yang efektif untuk kemampuan BSF dalam mereduksi sampah ialah setiap hari dengan nilai residu cair yang lebih sedikit dibandingkan dengan reaktor AY (Feeding 5 hari +350 larva $+18 \mathrm{ml} \mathrm{EM} 4+1.5 \mathrm{~kg}$ sampah) dan reaktor perlakuan kontrol $\mathrm{K}$ (Feeding 3 hari + 350 larva + $18 \mathrm{ml} \mathrm{EM} 4+1.5 \mathrm{~kg}$ sampah).

\subsection{Residu Cair}

Proses dalam mereduksi sampah organik oleh larva BSF menghasilkan residu padat, selain itu juga menghasilkan residu cair. Residu cair yang dihasilkan pada tiap reaktor cukup tinggi, hal ini dikarenakan kadar air selama running juga cukup tinggi. Menurut Diener dkk (2011) bahwa dalam penelitian terdahulu dikatakan bahwa kadar air yang berlebihan dapat menghalangi atau mengganggu proses dekomposisi.

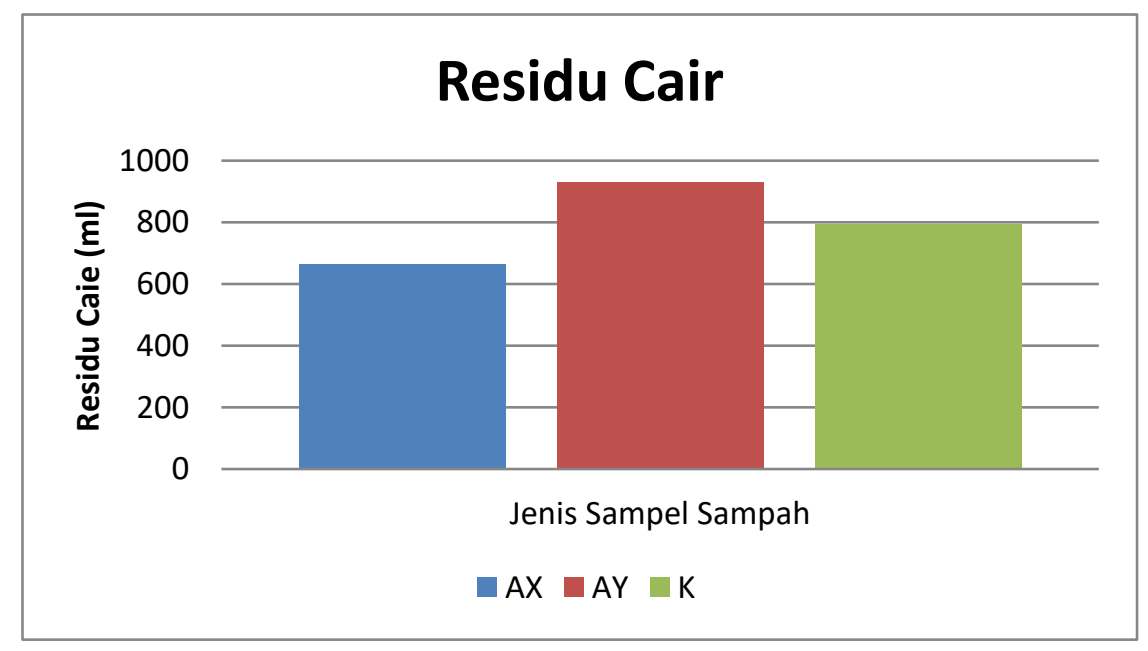

Gambar 3. 9 Grafik Residu Cair 
Berdasarkan Gambar 4.6 pada semua reaktor terlihat perbedaan residu cair yang signifikan. Pada reaktor AX (Feeding 1 hari $+0.3 \mathrm{~kg}$ sayur $+1.2 \mathrm{~kg}$ buah +350 larva $+18 \mathrm{ml}$ EM4) memiliki nilai residu cair yang lebih sedikit dengan rata-rata sebesar $665 \mathrm{ml}$ dibandingkan dengan reaktor AY (Feeding 5 hari $+0.3 \mathrm{~kg}$ sayur $+1.2 \mathrm{~kg}$ buah +350 larva $+18 \mathrm{ml}$ EM4) memiliki nilai residu cair yang lebih tinggi dengan rata-rata sebesar $930 \mathrm{ml}$, nilai residu cair reaktor AY lebih tinggi dibandingkan dengan reaktor $\mathrm{AX}$ dan $\mathrm{K}$ (Feeding 3 hari $+0.3 \mathrm{~kg}$ sayur $+1.2 \mathrm{~kg}$ buah +350 larva + $18 \mathrm{ml}$ EM4). Sedangkan reaktor perlakuan kontrol K (Feeding 3 hari $+0.3 \mathrm{~kg}$ sayur $+1.2 \mathrm{~kg}$ buah + 350 larva + $18 \mathrm{ml}$ EM4) memiliki nilai rata-rata residu cair sebesar $792 \mathrm{ml}$. tingginya kadar air sangat berpengaruh pada residu cair yang dihasilkan, kadar air yang terlalu tinggi pada pakan berdampak pada kondisi residu (produk), menyebabkan residu terlalu basah dan lengket sehingga sulit untuk dipisahkan.

\subsection{Pengaruh Frekuensi Feeding Terhadap Persentase Reduksi Sampah Oleh Larva BSF}

Uji anova dilakukan dengan menggunakan nilai signifikan 0,05 atau tingkat kepercayaan 95\%. Berdasarkan hasil analisis uji anova, diperoleh bahwa tterdapat interaksi antara frekuensi feeding terhadap besar persentase reduksi sampah. Hasil analisis statistik uji anova dapat dilihat pada Tabel berikut.

Tabel 3.4 Uji Statistik Annova One Way

Anova: Single Factor

\begin{tabular}{|c|c|c|c|c|}
\hline Groups & Count & Sum & Average & Variance \\
\hline $\begin{array}{l}\text { Feeding } 1 \text { hari }+0,3 \mathrm{~kg} \text { sayur } \\
+1,2 \mathrm{~kg} \text { buah }+350 \text { larva } \\
\text { Feeding } 3 \text { hari }+0,3 \mathrm{~kg} \text { savur }\end{array}$ & 2 & 5335 & 2667.5 & 37812.5 \\
\hline $\begin{array}{l}+1,2 \mathrm{~kg} \text { buah }+350 \text { larva } \\
\text { Feeding } 5 \text { hari }+0,3 \mathrm{~kg} \text { sayur }\end{array}$ & 2 & 4863 & 2431.5 & 28084.5 \\
\hline$+1,2 \mathrm{~kg}$ buah +350 larva & 2 & 3015 & 1507.5 & 112.5 \\
\hline
\end{tabular}

\begin{tabular}{|c|c|c|c|c|c|c|}
\hline Source of Variation & $S S$ & $d f$ & $M S$ & $F$ & P-value & $F$ crit \\
\hline Between Groups & 1503381 & 2 & 751690.7 & 34.16284 & 0.008626 & 9.552094 \\
\hline Within Groups & 66009.5 & 3 & 22003.17 & & & \\
\hline Total & 1569391 & 5 & & & & \\
\hline
\end{tabular}

Berdasarkan data pada Tabel 3.4 hasil analisis statistik uji anova dapat dilihat pada $P$-Value frekuensi feeding menunjukan nilai sig lebih kecil dari 0,05 maka diperoleh kesimpulan $\mathrm{H} 1$ diterima. Kesimpulan ini menunjukan bahwa terdapat interaksi nyata atau sama antara frekuensi feeding dengan persentase reduksi sampah. 


\section{KESIMPULAN}

Persentase terbesar reduksi sampah oleh larva BSF dari hari ke-1 sampai hari ke-15 penelitian ada pada reaktor yang berisi 350 larva, $1.5 \mathrm{~kg}$ sampah, $18 \mathrm{ml}$ EM4 dan frekuensi feeding 1 hari yaitu sebesar $71 \%$ dan persentase reduksi sampah terkecil ada pada reaktor yang berisi 350 larva, $1.5 \mathrm{~kg}$ sampah, $18 \mathrm{ml}$ EM4 dan frekuensi feeding 5 hari yaitu sebesar 60\%. Berdasarkan hasil uji statistik one way annova menunjukkan bahwa terdapat perbedaan atau interaksi nyata antara frekuensi feeding dengan persentase reduksi sampah.

\section{DAFTAR PUSTAKA}

Cintaningtyas, E., B., Utami., \& M. Nurmilawati. 2020. Efisiensi Degradasi Sampah Organik oleh Larva Black Soldier Fly. Jurnal Biologi dan Pembelajarannya (JB\&P), 7(2), 15-18.

Diener, S. 2011. A Dissertation : Valorisation of Organik Solid Waste Using the Black Soldier Fly, Hermetia illucens, in Low and Middle-Income Countries: Swiss.

Fazriansyah, M. 2020. Pemanfaatan Larva Black Soldier Fly (Hermetica Illucens) Sebagai Pereduksi Sampah Organik Dengan Variasi Jenis Makanan dan Frekuensi Feeding. Skripsi. Universitas Lambung Mangkurat. Banjarbaru.

Jatmiko, F. T. 2021. Kajian Literatur Pemanfaatan Larva Black Soldier Fly (Hermetia Illucens) dalam Pengomposan Sampah Organik. Skripsi. Universitas Islam Indonesia. Yogyakarta.

Nursaid, A.A., Yurlandala, Y. \& Maziya, F.B. 2019. Analisis Laju Penguraian dan Hasil Kompos Pada Pengolahan Sampah Buah dengan Larva Black Soldier Fly (Hermetia illucens). Skripsi. Islamic University of Indonesia. Yogyakarta.

Rahayu, T. P., E. D. Novianto., \& C. D. N. Viana. 2020. Pengaruh Lama Fermentasi Dedak dan Limbah Kulit Nanas Terhadap Biomassa Larva Hermetia Illucens. Jurnal Sains Peternakan. 8(2): 114-121.

Rofi, D. Y. 2020. Teknologi Reduksi Sampah Organik Buah dan Sayur dengan Modifikasi Pakan Larva Black Soldier Fly. Skripsi. Universitas Islam Negeri Sunan Ampel. Surabaya.

Sipayung, P. Y. E. 2015. Pemanfaatan Larva Black Soldier Fly (Hermetia Illucens) sebagai Salah Satu Teknologi Reduksi Sampah di Daerah Perkotaan. Skripsi. Institut Teknologi Sepuluh Nopember. Surabaya.

Sugiananda, A. 2020. Pemanfaatan Larva Black Soldier Fly (Hermetica Illucens) Sebagai Teknologi Reduksi Sampah Organik Dengan Variasi Jumlah Larva dan Kuantitas Feeding. Skripsi. Universitas Lambung Mangkurat. Banjarbaru.

Surung. 2008. Pengaruh Dosis EM4 (Effective Microorganism 4) pada Pembuatan Biogas dari Enceng Gondok dan Rumen Sapi. Jurnal Agrisistem. 4(4). 40-47. 
JTAM Tenik Lingkungan Universitas Lambung Mangkurat, Vol 4 (2) Tahun 2021

Halaman ini sengaja dikosongkan 